\title{
Innovational Development for Transitional Economy - Russia Case Study
}

\author{
Valeria A. Arsenyeva', Svetlana A. Litvinova'1, Valentina N. Parakhina², Zinaida N. Kozenko ${ }^{3}$, Mikhail Y. Denisov ${ }^{4}$
}

ABSTRACT The purpose of this article is to develop mechanisms of innovational development for countries
with transitional economies. The methodological base of the research consists of a factor analysis
of the structure of GDP adapted to the analysis of the innovational development of countries with
a transitional economy, distinguishing the innovational sphere of the economy, the structure of
manufactured innovational goods, the structure of the creation of leading production technolo-
gies, and the structure of the leading production technologies.
During the course of the research, the authors determined the key problems inhibiting innova-
tional development in Russia and other countries with transitional economies, determined the
most important preconditions of Russia's transition to an innovation-oriented type of economic
development, and offered instruments for Russia's transition to an innovation-oriented type of eco-
nomic development. As a result, the authors developed working mechanisms of the innovational
development of countries with a transitional economy.
The authors come to the conclusion that the innovational development of an economy is an impor-
tant condition for the adaptation of countries with a transitional economy to new market conditions
because it allows the private manufacturing of products that are competitive in global markets. High
innovational activity is one of the most important features of a market economy compared to an
administrative \& command economic system; thus, without the development of innovations, tran-
sitioning to a new type of economic system is impossible for countries with a transitional economy.

KEY WORDS: innovational development, countries with transitional economy, leading production technologies, modern Russia

JEL Classification: $\quad 0110,0380$, P210

'South-Russian Institute of Management - Branch of Russian Presidential Academy of National Economy and Public Administration, Russia; ${ }^{2}$ North Caucasus Federal University, Russia; ${ }^{3}$ Volgograd State Agrarian University, Russia; ${ }^{4}$ Rostov State Economic University (RINH), Russia

\section{Introduction}

Major participants in international economic relations and important components of the global economy are

Correspondence concerning this article should be addressed to: Valeria Arsenyeva, South-Russian Institute of Management Branch of Russian Presidential Academy of National Economy and Public Administration 70 Pushkinskaya St. , Rostov-on-Don 344002, Russian Federation. Email: valeria-arsenyeva@rambler.ru countries with transitional economies, which possess unique capabilities related to the transitional nature of their economic systems that are caused by changes in the management type and foundations of the conduct of economic activities.

Although these countries comprise a large and separate block of the modern global economic system, they do not contribute much to its development because they are mainly concentrated on solving internal prob- 
lems related to the stabilization of economic development and termination of the transitional period.

Multiple examples prove that innovations make it possible to overcome crises in the economy. The transitional period of economic development can also be considered a type of crisis of an economic system. A country may not fully realize its existing potential due to periodic systemic errors, a lack of clear rules that are understandable to all members of the economic system, and a lack of cooperation between various institutes.

According to the expectations of most modern economists, innovational development will help countries with a transitional economy pass to a new stage and end the transitional period. The main problem is insufficiently high levels of innovational development and a lack of working mechanisms for the activation of innovational activity in countries with a transitional economy.

It is important to note that such countries require special mechanisms that are adapted to the specifics of their nation, the level of development of their institutional environment and the general social mood in their society and business environment. This determines the actuality of the development of such mechanisms, which is studied in this research. The purpose of this article is to develop mechanisms of innovational development for countries with a transitional economy by using the example of modern Russia.

This goal is achieved by determining the foundations and tendencies of current innovational development in countries with a transitional economy, determining key problems and preconditions of the transition of countries with a transitional economy to an innovation-oriented type of economic development, and developing the corresponding instruments.

\section{Literature review}

The theoretical base of the research includes works of modern authors in the sphere of economic growth on substantiating the necessity and importance of the growth of economic systems to achieve the development of the global economy; determining the preconditions and factors of economic growth; and determining obstacles to the growth and development of the modern global economy and the means and methods of their elimination. Such authors include (Bartolini \&
Sarracino, 2015; González-Pernía \& Peña-Legazkue, 2015; Odhiambo, 2015; Pogosov, 2015; Popkova, Yurev, Stepicheva, \& Denisov, 2005; Zeira \& Zoabi, 2015). Economic growth is very important and necessary for the development of the global economy (Choi \& Shin, 2015). A precondition of economic growth is high entrepreneurial and innovational economic activity (Lee \& Oh, 2015). The state can stimulate economic growth by financing scientific research, creating favorable conditions for business, and attracting foreign investments (Castiglione, Infante, \& Smirnova, 2015).

This article also uses the theoretical research of economists in the sphere of innovational development of economic systems, in which the role of innovations in the development of economic systems is studied, the role of state regulation and the initiatives of private business in the provision of economic innovational development is determined, and regularities and terms of innovational development are analyzed. Such authors include (Appe, 2015; Imanbekova, 2014; Solovchuk, 2015). Despite the state financing of science and education, innovations are implemented by private business, which is a ley source of innovations in the economy (Zhao \& Sun, 2014). Innovational development can be evolutional, via the implementation of insignificant improvements (Baldwin, Black, \& O’Leary, 2014), or revolutionary, via the establishment of completely new technological modes (Tovt, 2014).

In addition, the work uses the studies of scientists assessing the methodical and practical aspects of economic growth and mechanisms of innovational development of the economies of modern countries, in which the effectiveness of various innovational tools is determined and issues of the use of various models of innovational development are viewed with the example of countries and regions. These authors include (Castellacci, 2015; Coccia, 2015; Donate, Peña, \& Sánchez de Pablo, 2015; Rumyantsev, 2015; Scherer \& Voegtlin, 2015; Vasin \& Gamidullaeva, 2015). In Russia, the state is the member of economic relations that has the most initiative and expresses an interest in the creation and implementation of innovations (Lillis, Szwejczewski, \& Goffin, 2015).

This is caused by the relative isolation of the economy of modern Russia and a low level of competition (Kolychev \& Prokhorov, 2015). In developed countries, competition creates stimuli for the imple- 
mentation of innovations for private enterprises $(\mathrm{Ng}$, Kanagasundram, Wong, \& Chandran, 2015). The authors also use the works of various researchers studying the peculiarities of the development of countries with transitional economies, which are known as transit economies, as well as those studying the most important aspects of the functioning of an economy during transitional periods from an administrative \& command system to a market system and determining preconditions for the end of transitional periods. Such works include (Akimov, 2015; Andres \& Round, 2015; Askarov \& Doucouliagos, 2015; Borgersen \& King, 2015; Makanyeza \& Du Toit, 2015; Mutlu, Zhan, Peng, $\&$ Lin, 2015). Countries with a transitional economy include countries of the former USSR, one of which is modern Russia (Boermans \& Roelfsema, 2015). The transitional character of the economy supposes refusal from administrative and command state management and the transition to the development of a market economic system (Hong, Hong, Wang, Xu, \& Zhao, 2015). Currently, countries of the former USSR have not yet come to the end of the transitional period (Dovlatyan, Makeeva, Oboymova, \& Cherkesova, 2015)

\section{Method}

The methodological basis of the research is comprised of factor analysis, adapted to the analysis of innovational development of countries with a transitional economy. Within this approach, the initial point of conduct of the analysis is the development of an economic model. This research builds a structural model of GDP with the allocation of the innovational sphere of the economy, which has the following form:

$\mathrm{GDP}_{\mathrm{i}}=\mathrm{IP}_{\mathrm{i}}+\mathrm{AP}_{\mathrm{i}}+\mathrm{SS}_{\mathrm{i}}+\mathrm{IN}_{\mathrm{i}}$

where GDP - gross domestic product in a certain year; IP - volume of industrial production of industrial products that are not innovational in a certain year;

AP - volume of agricultural production of food products that are not innovational in a certain year;

SS - volume of provision of services that are not innovational within the sphere of service and trade in a certain year;

IN - volume of innovational products manufactured in all spheres of economy in a certain year; and $\mathrm{i}$ - studied period of time (year).
The next stage of the factor analysis is the collection of statistical information to determine the value of indicators in both the studied year and the year prior. Then, a calculation table is built, into which the values of the indicator for the studied two-year period are entered in a special way. The upper and first lines of the table consist of statistical data for the previous year, the second line consists of the same information replaced with the value of the indicators of the IN data for current year, and the third line consists of the indicators' values for previous year.

The final stage of the factor analysis is to determine the contribution of the studied factor or several studied factors in the innovational development of countries with a transitional economy using the following formula:

$\Delta \mathrm{GDP}(\mathrm{IN})=\mathrm{GDP}_{\mathrm{IN}}-\mathrm{GDP}_{\mathrm{i}-1}$

In equation (2), GDP ${ }_{\text {IN }}$ is the growth of GDP by means of an increase in the volume of manufactured innovational products. That is, all components of GDP are taken for the previous year, and the indicator of innovational activity is taken for the current (studied) year. This difference is significant because it makes it possible to determine the contribution of the factor of innovational activity to the growth of GDP in the current year.

In addition to the determination of contribution of innovations to the formation of GDP of a country with a transitional economy, the complex analysis of its innovational development requires a factor analysis of the structure of manufactured innovational goods. For this, the authors of this research offer the following model:

$\mathrm{IP}_{\mathrm{i}}=\mathrm{ME}_{\mathrm{i}}+\mathrm{PP}_{\mathrm{i}}+\mathrm{DE}_{\mathrm{i}}+\mathrm{CM}_{\mathrm{i}}+\mathrm{CT}_{\mathrm{i}}+\mathrm{OS}_{\mathrm{i}}$

Where IP - total volume of manufactured innovational products in a certain year;

$\mathrm{ME}$ - volume of manufactured innovational goods in a certain year in the sphere of minerals extraction; PP - volume of manufactured innovational goods in a certain year in the sphere of processing production; $\mathrm{DE}$ - volume of manufactured innovational goods in a certain year in the sphere of the production and distribution of electricity, gas, and water; 
$\mathrm{CM}$ - volume of manufactured innovational goods in a certain year in the sphere of telecommunications;

CT - volume of manufactured innovational goods in a certain year in the sphere of computational technics use and informational technologies; and

OS - volume of manufactured innovational goods in a certain year in the sphere of the provision of other types of services.

Within this, a calculation model is built, into which the values of the indicators for the studied two-year period are entered in a special way. The upper and first lines of the table include statistical information on previous year; the second, third, fourth, fifth, sixth, and seventh lines include the same information replaced with the values of the targeted studied indicators for the studied year; and the last, eighth, line includes information for the current year.

To create a general notion on the nature of innovational development of a country with a transitional economy, it is important to know the structure of the creation of leading production technologies. We use the following model:

$\mathrm{LPT}_{\mathrm{i}}=\mathrm{NGC}_{\mathrm{i}}+\mathrm{CNT}_{\mathrm{i}}+\mathrm{UPI}_{\mathrm{i}}$

where LPT - total number of developed leading production technologies in a certain year;

NGC - number of leading production technologies that are new for the given country, in a certain year;

CNT - number of completely new leading production technologies in a certain year; and

UPI - number of new leading production technologies with the use of patented inventions with the development of technology in a certain year.

Finally, it is necessary to determine the structure of the used leading production technologies according to the following formula:

$\mathrm{UPT}_{\mathrm{i}}=\mathrm{TDP}_{\mathrm{i}}+\mathrm{TFP}_{\mathrm{i}}$

where UPT - total number of leading production technologies used in this country in a certain year;

TDP - number of leading production technologies of domestic production used in this country in a certain year; and
TFP - total number of leading production technologies of foreign production used in this country in a certain year.

For this model, the data are shown in the following table.

\section{Results}

The largest representative of countries with a transitional economy is the Russian Federation. Considering the similar features of such countries, it suffices to view tendencies of innovational development of modern Russia because they can later be applied, with a high level of authenticity and representation, to other countries with a transitional economy. To determine the sense and tendencies of current innovational development in Russia, let us conduct a factor analysis on the basis of the compiled models (Table 1-4).

As seen from the results of the factor analysis, the increase in the manufacturing of innovational products stimulated the growth of the Russian GDP in 2014, compared to 2013, by RUB 574.3 billion (6\%). Thus, the growth of innovational products contributed only slightly to the development of national production, reflecting a low level of innovational development of the modern Russian economy.

The largest growth of innovational products in 2014 , compared to 2013, was observed in the sphere of processing productions (95\%), and the contribution of each other sphere to the growth in the volume of manufactured innovational goods constituted less than $1 \%$. The largest share in the structure of created innovations in 2013-2014 belonged to innovations that are new for Russia but not new for the world. In 2014, the volume of created innovations decreased compared to the level of 2013.

The number of implemented foreign investments significantly exceeded the number of implemented foreign investments in Russia in 2013-2014. The total volume of innovations, implemented into production, decreased over the studied period. Among the key problems of innovational development of Russia and other countries with a transitional economy, it is possible to distinguish the following:

- the creation of innovations that are a novelty only for this country and have long been known around the world; 
Table 1. Summarized calculation table for conduct of factor analysis of the role of innovations in formation of GDP of countries with a transitional economy, RUB billion

\begin{tabular}{lccccc}
\hline & IP & AP & SS & IN & GDP \\
\hline $\mathrm{GDP}_{2013}$ & $42,155.3$ & $5,140.9$ & $66,945.8$ & $2,588.9$ & $116,831.0$ \\
$\mathrm{GDP}_{\text {IN }}$ & $42,155.3$ & $5,140.9$ & $66,945.8$ & $3,163.2$ & $117,405.3$ \\
$\mathrm{GDP}_{2014}$ & $45,395.4$ & $5,536.0$ & $72,091.4$ & $3,163.2$ & $126,186.0$ \\
\hline
\end{tabular}

Source: Adapted from "Russia in numbers. Scientific research and innovations 2015: Bulletin of Rosstat" by Rosstat (2015). Retrieved from Retrieved from http://www.gks.ru/free_doc/doc_2015/rusfig/rus-15.pdf

Table 2. Summarized calculation table for a factor analysis of innovational development for countries with a transitional economy, RUB million

\begin{tabular}{lccccccc}
\hline & ME & PP & DE & CM & CT & OS & IP \\
\hline $\mathbb{P}_{2013}$ & $522,890.9$ & $1,973,535.6$ & $13,177.9$ & $41,444.1$ & $14,648.1$ & $23,251.3$ & $2,588,948$ \\
$\mathbb{P}_{M E}$ & $523,210.5$ & $1,973,535.6$ & $13,177.9$ & $41,444.1$ & $14,648.1$ & $23,251.3$ & $2,589,268$ \\
$\mathbb{P}_{\mathrm{PP}}$ & $522,890.9$ & $2,518,618$ & $13,177.9$ & $41,444.1$ & $14,648.1$ & $23,251.3$ & $3,134,030$ \\
$\mathbb{I}_{\mathrm{DE}}$ & $522,890.9$ & $1,973,535.6$ & $30,702.2$ & $41,444.1$ & $14,648.1$ & $23,251.3$ & $2,606,472$ \\
$\mathbb{P}_{\mathrm{CM}}$ & $522,890.9$ & $1,973,535.6$ & $13,177.9$ & $31,535.7$ & $14,648.1$ & $23,251.3$ & $2,579,040$ \\
$\mathbb{I}_{\mathrm{CT}}$ & $522,890.9$ & $1,973,535.6$ & $13,177.9$ & $41,444.1$ & $39,558.7$ & $23,251.3$ & $2,613,859$ \\
$\mathbb{P}_{\text {OS }}$ & $522,890.9$ & $1,973,535.6$ & $13,177.9$ & $41,444.1$ & $14,648.1$ & $19,590.8$ & $2,585,287$ \\
$\mathbb{I}_{2014}$ & $523,210.5$ & $2,518,618$ & $30,702.2$ & $31,535.7$ & $39,558.7$ & $19,590.8$ & $3,163,216$ \\
\hline
\end{tabular}

Source: Adapted from "Russia in numbers. Scientific research and innovations 2015: Bulletin of Rosstat" by Rosstat (2015). Retrieved from Retrieved from http://www.gks.ru/free_doc/doc_2015/rusfig/rus-15.pdf

Table 3. Summarized calculation table for a factor analysis of the developed leading production technologies in countries with a transitional economy

\begin{tabular}{lcccc}
\hline & NGC & CNT & UPI & LPT \\
\hline $\mathrm{LPT}_{2013}$ & 1,276 & 153 & 694 & 2,123 \\
$\mathrm{LPT}_{\text {NGC }}$ & 1,245 & 153 & 694 & 2,092 \\
$\mathrm{LPT}_{\text {CNT }}$ & 1,276 & 164 & 694 & 2,134 \\
$\mathrm{LPT}_{\text {UP1 }}$ & 1,276 & 153 & 712 & 2,141 \\
$\mathrm{LPT}_{2014}$ & 1,245 & 164 & 712 & 2,121 \\
\hline
\end{tabular}

Source: Adapted from "Russia in numbers. Scientific research and innovations 2015: Bulletin of Rosstat" by Rosstat (2015). Retrieved from Retrieved from http://www.gks.ru/free_doc/doc_2015/rusfig/rus-15.pdf

Table 4. Summarized calculation table for a factor analysis of the leading production technologies in countries with a transitional economy

\begin{tabular}{lccc}
\hline & TDP & TFP & UPT \\
\hline UPT $_{2013}$ & 117,697 & 40,544 & 158,241 \\
UPT $_{\text {TDP }}$ & 110,037 & 40,544 & 150,581 \\
UPT $_{\text {TFP }}$ & 117,697 & 48,068 & 165,765 \\
UPT $_{2014}$ & 110,037 & 48,068 & 158,105 \\
\hline
\end{tabular}

Source: Adapted from "Russia in numbers. Scientific research and innovations 2015: Bulletin of Rosstat" by Rosstat (2015). Retrieved from Retrieved from http://www.gks.ru/free_doc/doc_2015/rusfig/rus-15.pdf 


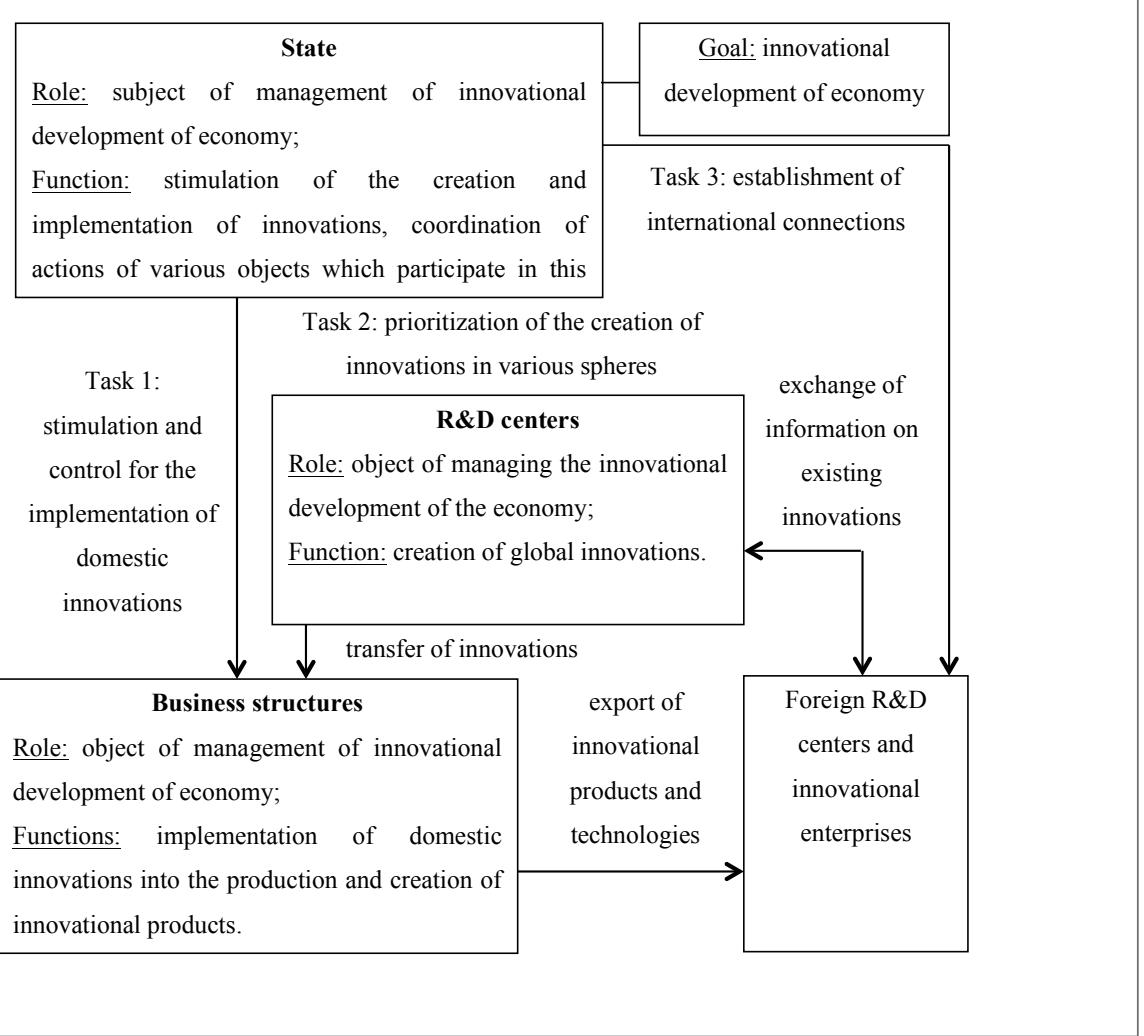

Figure 1. Mechanisms of innovational development of countries with a transitional economy

- the concentration of created innovations in the spheres of economy that develop actively, which contradicts the idea of diversification; and

- an excessive orientation towards the use of foreign investments and refusal to implement new domestic developments into production.

The most important preconditions of Russia's transition to an innovation-oriented type of economic development include the following:

- society's realization of the necessity, social readiness, and approval of a transition to an innovational path of economic development;

- significant accumulated scientific and technical potential of the economy; and

- the development of the resource component of production.
The following mechanisms are offered in this research as instruments for Russia's transition to an innovationoriented type of economic development (Fig. 1):

- the establishment of international connections for acquaintance with popular innovations - for the purpose of preventing their repeated invention;

- the creation of an international committee for the evaluation of the level of innovativeness of new developments throughout the world;

- the establishment of priorities for the creation of innovations in new spheres of the economy for its diversification; and

- the stimulation of the implementation of domestic innovations through the provision of tax concessions.

The offered mechanisms of innovational development of countries with a transitional economy are given in Fig. 1. 


\section{Conclusion}

As a result of this research, the set goal was achieved by using the set tasks. The offered mechanisms of innovational development in countries with a transitional economy are aimed at state stimulation and control for the implementation of domestic innovations, the prioritization of the creation of innovations in various spheres, and the establishment of international connections to increase the quantity and quality (level of novelty for the world) of created innovations and to create favorable conditions for the implementation of domestic innovations in production.

These mechanisms make it possible to overcome the existing problems in the way of the Russian economy's transition to innovational development. The subject of management within the developed mechanisms is the state, and the object of management is $\mathrm{R} \& \mathrm{D}$ centers in the country and domestic business structures.

It is important to note that the innovational development of an economy is an important condition for the adaptation of countries with a transitional economy to new market conditions because they enable the development of private manufacturing of products that are competitive in the global markets. High innovational activity is one of the most important peculiarities of a market economy compared to an administrative and command economic system. Without the development of innovations, transition to the new type of economic system of countries with a transitional economy is impossible.

It should be noted that this article does not study all of the characteristics of innovational development for countries with a transitional economy but focuses instead on only the main ones. This limitation, which affects the results of the conducted research, is due to the limited length of the article. During further research in the sphere of innovational development in countries with a transitional economy, it would be expedient to view other aspects.

\section{References}

Akimov, A. (2015). The Political Economy of Financial Reforms in Authoritarian Transition Economies: A Comparative Studies in Kazakhstan and Uzbekistan. In K. Ruziev \& N. Perdikis (Eds.), Development and Financial Reform in Emerging Economies (pp. 125-147). United Kingdom, UK: Pickering and Chatto.
Andres, L., \& Round, J. (2015). The creative economy in a context of transition: A review of the mechanisms of micro-resilience. Cities, 45, 1-6.

Appe, S. (2015). Government mapping of the third sector: a government innovation for regulation and coordination? Perspectives from the third sector. International Journal of Public Administration, 38(10), 724-733.

Askarov, Z., \& Doucouliagos, H. (2015). Aid and institutions in transition economies. European Journal of Political Economy, 38, 55-70.

Baldwin, R., Black, J., \& O’Leary, G. (2014). Risk regulation and transnationality: institutional accountability as a driver of innovation. Transnational Environmental Law, 3(2), 373-390.

Bartolini, S., \& Sarracino, F. (2015). The dark side of Chinese growth: Declining social capital and wellBeing in times of economic boom. World Development, 74, 333-351.

Boermans, M. A., \& Roelfsema, H. (2015). The effects of internationalization on innovation: Firm-level evidence for transition economies. Open Economies Review, 26(2), 333-350.

Borgersen, T. A., \& King, R. M. (2015). Endogenous supply side constraints to export-led growth and aggregate growth implications in transition economies. Structural Change and Economic Dynamics, 33, 96-109.

Castellacci, F. (2015). Institutional voids or organizational resilience? Business groups, innovation, and market development in Latin America. World Development, 70, 43-58.

Castiglione, C., Infante, D., \& Smirnova, J. (2015). Environment and economic growth: Is the rule of law the go-between? The case of high-income countries. Energy, Sustainability and Society, 5(26). doi:10.1186/s13705-015-0054-8.

Choi, K. H., \& Shin, S. (2015). Population aging, economic growth, and the social transmission of human capital: An analysis with an overlapping generations model. Economic Modelling, 50, 138-147.

Coccia, M. (2015). General sources of general purpose technologies in complex societies: Theory of global leadership-driven innovation, warfare and human development. Technology in Society, 42, 199-226. 
Donate, M. J., Peña, I., \& Sánchez de Pablo, J. D. (2016). HRM practices for human and social capital development: Effects on innovation capabilities. The International Journal of Human Resource Management, 27(9), 928-953.

Dovlatyan, G. P., Makeeva, E. I., Oboymova, N. T., \& Cherkesova, E. Y. (2015). Potential for use of foreign experience in evaluation of strategic sustainability of enterprises relating to transition of Russia's economy to strategic path of development. Asian Social Science, 11(20), 56-65.

González-Pernía, J. L., \& Peña-Legazkue, I. (2015). Export-oriented entrepreneurship and regional economic growth. Small Business Economics, 45(3), 505-522.

Hong, J., Hong, S., Wang, L., Xu, Y., \& Zhao, D. (2015). Government grants, private R\&D funding and innovation efficiency in transition economy. Technology Analysis and Strategic Management, 27(9), 1068-1096.

Imanbekova, M. (2014). The use of foreign experience in forming system state regulation of innovation activities of enterprises in the Republic of Kazakhstan. World Applied Sciences Journal, 30(5), 630-634.

Kolychev, V. D., \& Prokhorov, I. V. (2015). Conception, technology and methods of development of university system of innovation projects commercialization based on effectuation. Asian Social Science, 11(8), 44-51.

Lee, S., \& Oh, D.W. (2015). Economic growth and the environment in China: Empirical evidence using prefecture level data. China Economic Review, 36, 73-85.

Lillis, B., Szwejczewski, M., \& Goffin, K. (2015). The development of innovation capability in services: research propositions and management implications. Operations Management Research, 8(1), 48-68.

Makanyeza, C., \& Du Toit, F. (2015). Examining the measurement and dimensionality of the construct of consumer awareness in a developing and transition economy. SA Journal of Industrial Psychology, 41(1). doi: 10.4102/sajip.v41i1.1250

Mutlu, C. C., Zhan, W., Peng, M.W., \& Lin, Z. J. (2015). Competing in (and out of) transition economies. Asia Pacific Journal of Management, 32(3), 571-596.

Ng, B. K., Kanagasundram, T., Wong, C. Y., \& Chandran, V. G. R. (2015). Innovation for inclusive development in Southeast Asia: The roles of regional coordination mechanisms. The Pacific Review, 2(1), 1- 30.
Odhiambo, N. M. (2015). Government expenditure and economic growth in South Africa: An empirical envestigation. Atlantic Economic Journal, 43(3), 393-406.

Pogosov, I.A. (2015). Factors of long-term economic growth: Scientific and technical progress and capital intensity of production. Studies on Russian Economic Development, 26(5), 423-433.

Popkova, E. G., Yurev, V., Stepicheva, O., \& Denisov, N. (2015). Transformation and concentration of intellectual capital as a factor of economic growth in the modern economy. Regional and Sectoral Economic Studies, 15(1), 53-60.

Rosstat. (2015). Russia in numbers. Scientific research and innovations 2015: Bulletin of Rosstat. Retrieved from http://www.gks.ru/free_doc/ doc_2015/rusfig/rus-15.pdf

Rumyantsev, A. A. (2015). Science and innovation space of a macroregion: Prospects of innovative territorial development. Studies on Russian Economic Development, 26(4), 379-387

Solovchuk, K. О. (2015). Регулювання і підтримка інноваційної діяльності у сфері АПК в країнах Європейського Союзу. [Regulation and support for innovations in the agricultural sector of the European Union]. Actual Problems of Economics, 165(3), 62-68.

Tovt, T. I. (2014). Regulation mechanism for investment support of innovation activities of enterprises. Actual Problems of Economics, 152(2), 211-218.

Vasin, S. M., \& Gamidullaeva, L. A. (2015). Development a basic model of the innovation system. Review of European Studies, 7(11), 175-183.

Voegtlin, C., \& Scherer, A. G. (2015). Responsible innovation and the innovation of responsibility: Governing sustainable development in a globalized world. Journal of Business Ethics. Doi: 10.1007/s10551-015-2769-z.

Zeira, J., \& Zoabi, H. (2015). Economic growth and sector dynamics. European Economic Review, 79, 1-15.

Zhao, X., \& Sun, B. (2014). The influence of Chinese environmental regulation on corporation innovation and competitiveness. Journal of Cleaner Production, 112, 1523-1236. 